\title{
Biodegradation of Ammonium Ions and Formate During Ammonium Formate Metabolism by Yarrowia lipolytica and Pichia guilliermondii in a Batch Reactor
}

\author{
M. N. Nsoe • G. P. Kofa • K. S. Ndi • B. Mohammadou • \\ M. Heran • G. J. Kayem
}

Received: 10 January 2018 / Accepted: 12 April 2018/Published online: 5 May 2018

(C) The Author(s) 2018

\begin{abstract}
The use of microorganisms for the biodegradation of pollutants is increasingly being studied. But at high concentrations, these pollutants become rather inhibitors for the metabolism of microorganisms. In this study, the biodegradation of ammonium formate at various concentrations (1.59-7.94 $\mathrm{mM}$ ) by Yarrowia Lipolytica and Pichia guilliermondii isolated from the rubber effluent is studied by following the variation of ammonium ions and formate. A fitting of eight models of substrate inhibition was performed and the parameters were determined by nonlinear regression using MATLAB 8.5 ๑. The $R^{2}$ and the RSME allow to choose the best model. The results show that ammonium ions ( $3.17 \mathrm{mM}$ ammonium formate) are used as substrate; no inhibition is observed. But beyond this concentration, the inhibition effect begins to be observed with the
\end{abstract}

\footnotetext{
M. N. Nsoe $(\bowtie) \cdot B$. Mohammadou

Institute of Technology, University of Ngaoundere, P.O. Box 455, Ngaoundere, Cameroon

e-mail: nsoemenguenestor@yahoo.fr

M. N. Nsoe - G. P. Kofa • K. S. Ndi • G. J. Kayem

Water Treatment and Filtration Research (Chem. Eng.) Group,

Department of Process Engineering, ENSAI, University of

Ngaoundere, P.O. Box 455, Ngaoundere, Cameroon

G. P. Kofa

The Higher Institute of the Sahel (ISS), University of Maroua, P.O. Box 46, Maroua, Cameroon

M. Heran

Institute Europeen of Membrane UMR 5635

(CNRS-ENSCM-UMII), 005 - 34095, Montpellier CED, Place

Eugène Bataillon, France
}

specific rates of ammonium biodegradation which decrease. Formate monitoring reveals that is used as the main source of energy and does not inhibit the growth of yeasts. The models of Luong and Webb seem to be more appropriate for predicting the observed phenomena of inhibition. For Yarrowia lipolytica, $R^{2}=0.958$ and 0.998 with RSME $=0.005342$ and 0.003433 , for Pichia guillermondii, $R^{2}=0.999$ and 0.992 with $\mathrm{RSME}=$ 0.0005121 and 0.001212 .

Keywords Ammonium formate $\cdot$ Rubber wastewater . Batch reactor Y Yarrowia lipolytica.

Pichia guilliermondii $\cdot$ Inhibitor substrat

\section{Introduction}

Rubber production is in a full rise all over the world. It moved from 7 to 11 million tons in 2014 (LMC Rubber 2013). The harvested latex is usually stabilized by ammonia and then transported to the factory where it is coagulated by the addition of formic acid. Rubber industry produces large volume of wastewater which needs to be treated prior disposal in order to avoid malodorous problem and pollution effects in the receiving water. During the coagulation process, the reaction between ammonia and formic acid produces ammonium formate, which is the major component of wastewater and accounts for 23.4\% (Atagana et al. 1998). The ammonium formate is toxic and the risks of exposure vary from one concentration to another; transient and reversible effects on health are observed from 
$3.7 \mu \mathrm{g} \mathrm{L}^{-1} .41 \mu \mathrm{g} \mathrm{L}^{-1}$, these effects become harmful and irreversible (severe irritations and permanent damage to the eyes, irritation of the mucous membranes and respiratory tract, stomach pain, difficulty breathing, and finally gastrointestinal irritation, abdominal pain). Above $240 \mu \mathrm{g} \mathrm{L}^{-1}$, it leads to cell death (EPA USA 2016). The consumption of water containing the ammonium ion leads to the synthesis of carcinogenic nitrosamines, the formation of methaemoglobin in infants (Sulaiman et al. 2010; Arimoro 2009; Bougard 2004) and the inhibition of certain Pathways of the digestive and respiratory tract. At the environmental level, eutrophication of mangroves and rivers and the death of biological (Nsoe et al. 2016, Tekasakul 2010, Seneviratne 1997) are observed. The increase in ammonium ion concentrations in the environment leads in the long term to an imbalance of the nitrogen cycle and an acceleration of denitrification which can increase the concentrations of nitric oxide and nitrous oxide responsible for the destruction of the layer ozone. As for the formate ion, the reduction produces the $\mathrm{CO}_{2}$. Although its concentration in air is well below the toxicity threshold, emissions are not directly harmful to humans. On the other hand, $\mathrm{CO}_{2}$ emissions are mainly responsible for global warming, which can cause major health and safety problems for living organism (natural disasters, diseases, displacement of populations). This makes this compound the second most responsible for more than $39 \%$ of the destruction of the ozone layer. Given the health and environmental issues associated with ammonium formate, the need to eliminate this pollutant in these effluents before their release into the environment becomes an imperative. Sridhar et al. (2014), Peitz (2012), and Dobrovolná and Ervený (2000) proposed to fight ammonium formate by catalysis process. But by-products of this process $\left(\mathrm{HCONH}_{2}\right.$, $\mathrm{HCN}, \mathrm{NH}_{3}$ ) still represent a source of pollution for the environment. Moreover, the large volumes of waste water produced by these industries cannot be treated by this process which consumes a lot of energy. Biological treatments are increasingly explored for the treatment of these effluents (Ndi et al. 2016; Pillai and Girish 2014; Senthil et al. 2012; Swarna Smitha et al. 2012; Shruthi et al. 2012; Cheria and Jayachandran 2009). However, low purifying efficiencies have always been observed, mostly due to variations in the concentration of pollutants $\left(\mathrm{NH}_{3}\right)$ which become inhibitors even at low concentration (Vadivelu et al. 2007). In this case, mathematical modeling is useful for understanding the behavior of biological processes and predicting the concentrations of components in the system (Dutta et al. 2015; Tazda et al. 2013) to avoid inhibition and increase treatment efficiency. In this study, two strains of yeast (Yarrowia lipolytica and Pichia guilliermondii) were isolated from rubber effluents. The degradation of ammonium formate was monitored as well as the potential for inhibition of this molecule. The inhibitory effects of nitrogen on yeast were assessed and the experimental data were in accordance with the substrate inhibition model.

\section{Materials and Methods}

\subsection{Yeast Inoculum}

The yeast strains used in this work were isolated from the effluents of a rubber industry thanks to Nsoe protocol (Nsoe et al. 2013). The yeast characteristics are shown in Table 1.

Yeast were cultivated on the following growing medium (Atagana et al. 1998): meat extract $1 \mathrm{~g} \mathrm{~L}^{-1}$ (Sherlan réf 07-075, Spain), yeast extract $2 \mathrm{~g} \mathrm{~L}^{-1}$ (OXOID code L21, England), peptone $5 \mathrm{~g} \mathrm{~L}^{-1}$ (Liofilchem réf 610038, Italy), and sodium chloride $5 \mathrm{~g} \mathrm{~L}^{-1}$ (Jeulin réf 107115 , France) at $\mathrm{pH}=6.5$.

\subsection{Synthetic Influent}

The synthetic influent was built to ensure usually concentration found in rubber factories. Ammonium formate was the only source of carbon and nitrogen. It was added in order to cover different nitrogen concentrations: from 1.59 to $7.94 \mathrm{mM}$ (22.3 to $111 \mathrm{mg} \mathrm{N} \mathrm{L}^{-1}$ ). Ammonium formate were mixed to mineral salt medium (in $\mathrm{g} \mathrm{L}^{-1}$ ): $\mathrm{MgSO}_{4}(0.2), \mathrm{CaCl}$ (0.02), $\mathrm{KH}_{2} \mathrm{PO}_{4}(60), \mathrm{K}_{2} \mathrm{HPO}_{4}$ (14). A stock solution of microelements (in $\mathrm{g} \mathrm{L}^{-1}$ )—ZnSO4 (10.90), FeSO4 (5), MnSO4 (1.54), and CuSO4 (0.39) — was prepared and added to the influent at $0.1 \%(V / V)$. Then, $0.25 \mathrm{~g} \mathrm{~L}^{-1}$ of chloramphenicol was added to inhibit the bacterial growth and the synthetic influent was sterilized at $110{ }^{\circ} \mathrm{C}$ for $10 \mathrm{~min}$.

\subsection{Experimental Set-up: Batch Bioreactor}

Figure 1 shows us the Batch Bioreactor mounted for this experiment, it consists of several bioreactors of $1 \mathrm{~L}$ (with a useful volume of $0.8 \mathrm{~L}$ ) were used and immersed in a 
Table 1 Characteristics of yeast strains

\begin{tabular}{|c|c|c|c|c|c|c|}
\hline \multirow[t]{2}{*}{ Code } & \multirow[t]{2}{*}{ Yeast color } & \multirow{2}{*}{$\begin{array}{l}\text { Zeta potential } \\
\mathrm{pH}(5.7-7)\end{array}$} & \multirow[t]{2}{*}{ Yeast shape } & \multirow{2}{*}{$\begin{array}{l}\text { Yeast size } \\
(\mu \mathrm{m})\end{array}$} & \multicolumn{2}{|c|}{ Growth in selective media } \\
\hline & & & & & Acid medium & Alkaline medium \\
\hline $\begin{array}{l}\text { Yarrowia lipolytica } \\
\text { (LR) }\end{array}$ & Red & -25.3 to -37.8 & Ovoid & $0.3-150$ & + & + \\
\hline $\begin{array}{l}\text { Pichia guilliermondii } \\
\text { (LB) }\end{array}$ & White & -27.8 to -30.5 & Ovoid & $0.2-100$ & + & + \\
\hline
\end{tabular}

water bath to maintain the temperature at $25^{\circ} \mathrm{C}$. Aeration was supplied thanks to an air compressor (GIANESSIEDILIO, NML 58629, LT 100, ATE 12TEMPA, Italy) to ensure that dissolved $\mathrm{O} 2$ was not a limiting factor for biomass respiration and growth. In order to reduce bacterial contamination and $\mathrm{CO}_{2}$ content, air inlet undergoes a succession of washing solution with $1 \mathrm{mM}$ sodium hydroxide and $1 \mathrm{mM}$ hydrochloric acid. Then, air outlet was connected to a $500-\mathrm{mL}$ jar containing a $0.5 \mathrm{mM}$ sodium hydroxide solution in order to quantify the $\mathrm{CO}_{2}$ released during the catabolism of ammonium formate.

\subsection{Analytical Methods}

Samples were centrifuged at $1200 \mathrm{rpm}, 4^{\circ} \mathrm{C}$, and $10 \mathrm{~min}$. in 5000 $\mathrm{g}$ a Kendro-Heraeus PrimoR centrifuge (Biofuge, Germany). Then, ammonium ions $\left(\mathrm{NH}_{4}{ }^{+}\right)$where titrated by a portable mini-photometer of mark HANNA Checker
HC ® HI 733 Woonsocket RIUSE ROMANIE. The formate is determined by the method of the center of expertise in environmental analysis of Quebec code: MA.405-C11, 2014).

\subsection{Determination of Maximum Enzymatic Activity}

In order to establish the maximum enzymatic activity curve as a function of the substrate concentrations (formate and ammonium), the slope of the biodegradation kinetics curves of the substrate (formate and ammonium) as a function of time allows us to determine the enzyme activity for each strain at each substrate concentration.

\subsection{Calibration and Validation of Inhibition Model by Ammonium Formate}

A large set of different widely published substrate inhibition models were used to analyze experimental data

Fig. 1 Batch bioreactor

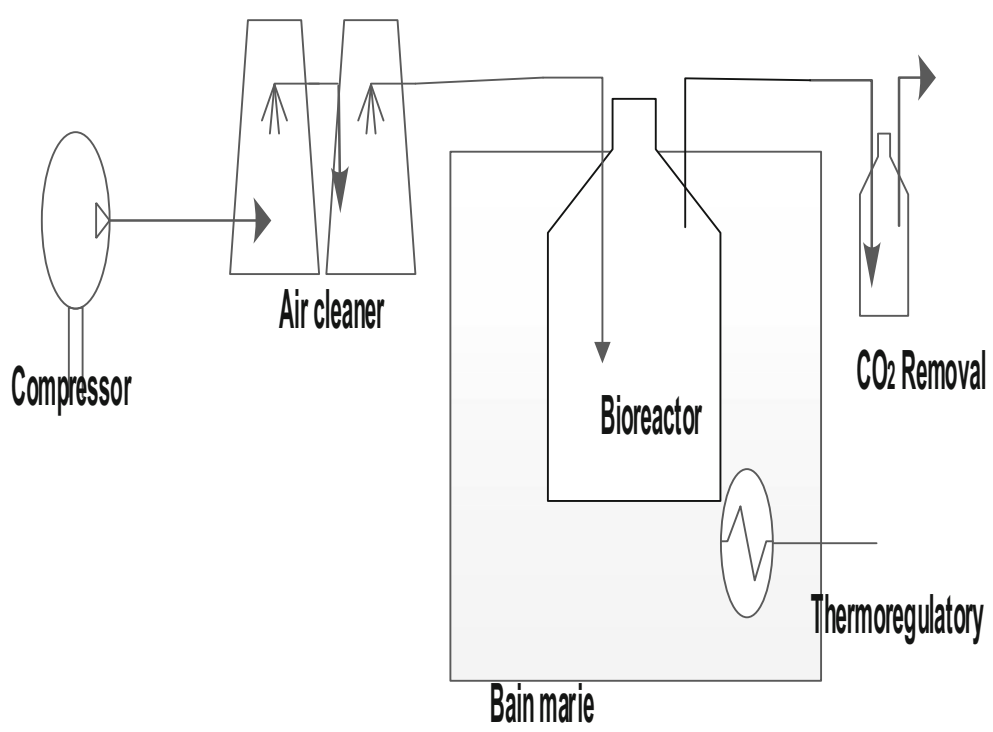


Table 2 Models of inhibition by the substrate (Dutta et al. 2015; Tazda et al. 2013; Agarry et al. 2010; Amrouche et al. 2010; Agarry and Solomon 2008)

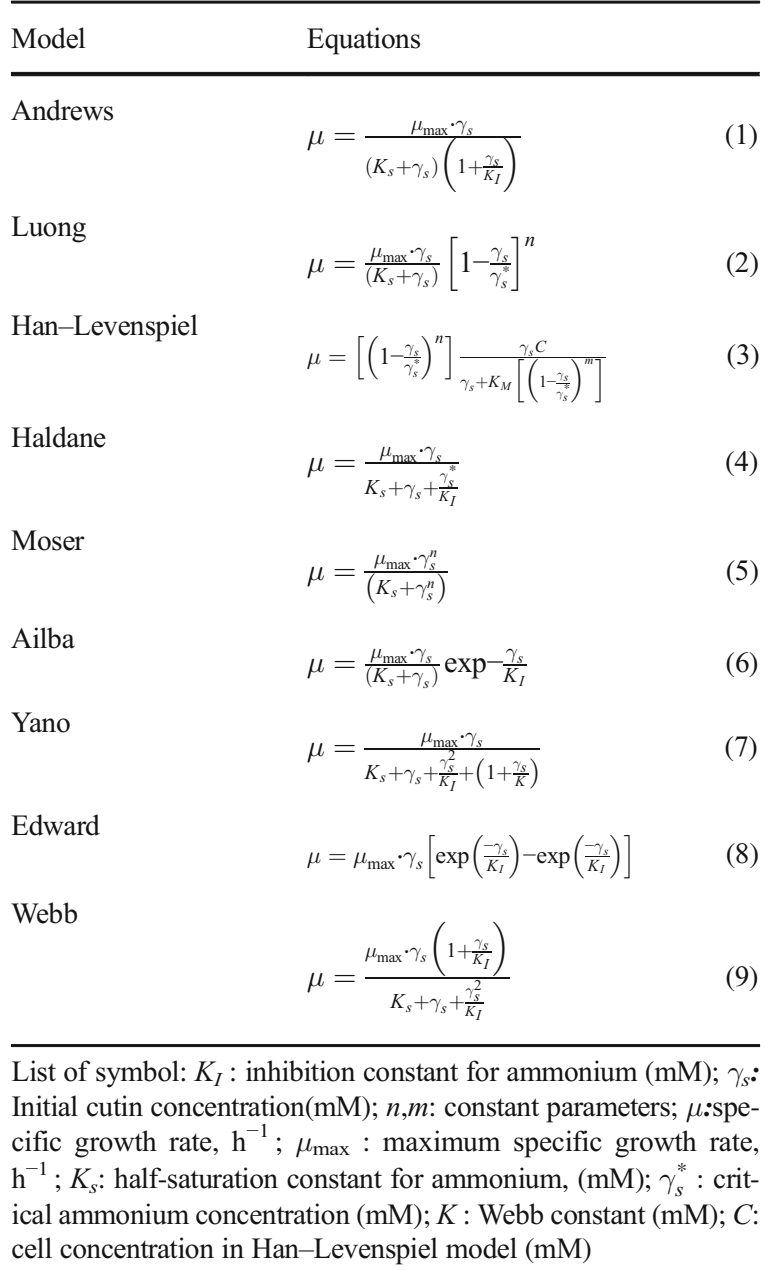

(Table 2). The parameters of different models were estimated from the experimental results using MATLAB v.7.1. Since the models had nonlinear coefficients, the parameters were estimated iteratively with nonlinear least square algorithm.

\section{Results and Discussion}

3.1 Kinetics of Ammonium Biodegradation by Yeast Strains at Different Concentrations of Ammonium Formate

Figures 2 and 3 show the variation of the ammonium ions as a function of time for each concentration of ammonium formate. We find that yeasts assimilate ammonium ions regardless of the concentration of ammonium formate because all curves have a decreasing rate. But the percentage of abatement varies from one strain to another and from one concentration to another. In addition to all the concentrations of ammonium formates, there is a latency time which shows that there is either an adaptation time for the biodegradation of ammonium ions or that this source of energy would be a source of energy which is not directly used by yeasts. In contrary, the percentage of ammonium ions catabolized by yeasts is inversely proportional to the concentration of the ammonium ions present in the medium. What shows that it is the ammonium ions could inhibit yeast metabolism.
Fig. 2 Variation of $\mathrm{NH}_{4}^{+}$as a function of time at different concentrations of ammonium formate for the Yarrowia lipolytica strain

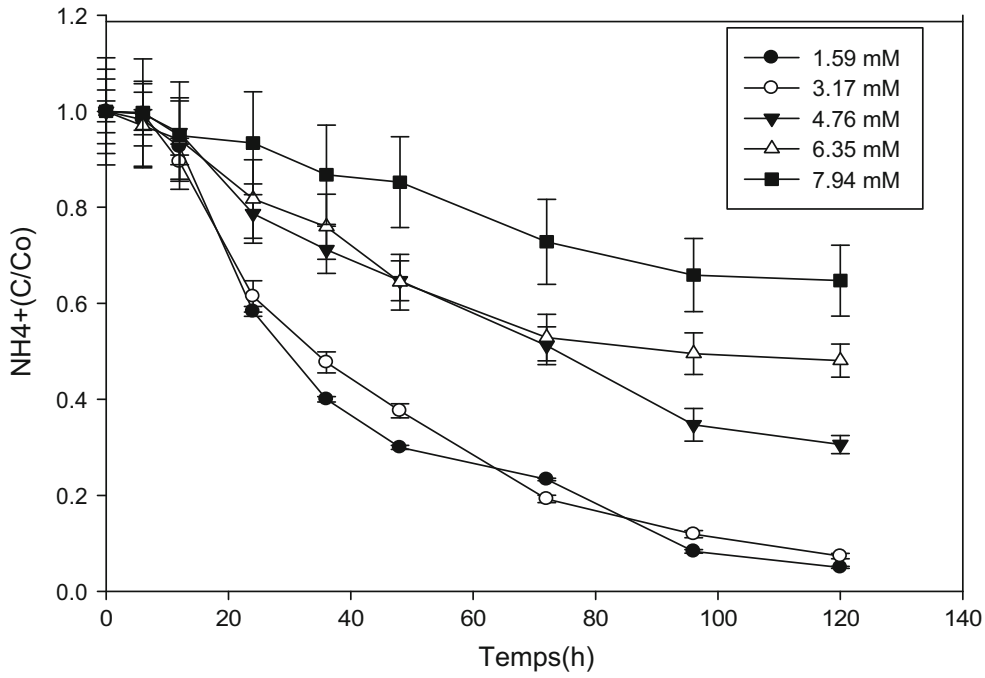


Fig. 3 Variation of $\mathrm{NH}_{4}^{+}$as a function of time at different concentrations of ammonium formate for the Pichia guilliermondii strain

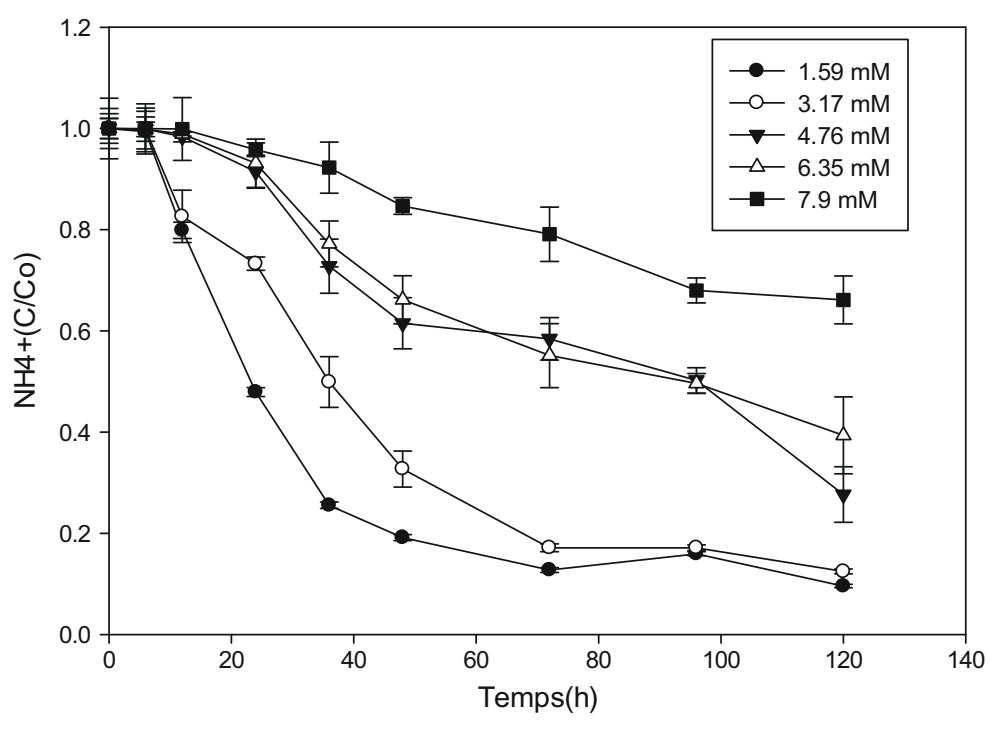

3.2 Kinetics of Biodegradation of Total Organic Carbon by Yeast Strains at Different Concentrations of Ammonium Formate

Figures 4 and 5 present the variation of formate as a function of time during the biodegradation of ammonium formate at different concentrations. All the figures present a decreasing pace whatever the strain without a latency time that might suggest that carbon is the main source of energy for growth yeasts compared to biodegradation curves of ammonium ions or there is a time of adaptation. We also find that for concentrations between 1.95 and $6.35 \mathrm{mM}$ in ammonium formate, the percentage of abatement of formate is $98 \%$ regardless of the strain. The shape of the curves at $7.94 \mathrm{mM}$ shows that this molecule is still being assimilated by yeasts and the percentage of abatement is lower.

3.3 Influence of Ammonium Concentration Maximum Enzymatic Activity

The maximum enzymatic activity as a function of the initial substrate concentration is shown in Fig. 6 for the two strains studied. These curves have a bell-like appearance and have two phases. A phase where the specific growth rates and maximal enzymatic activity increase with the formate concentration $(1.59-3.17 \mathrm{mM})$ and a phase of decline of the specific growth rate and
Fig. 4 Variation of formate as a function of time at different concentrations of ammonium formate for the Pichia guilliermondii strain

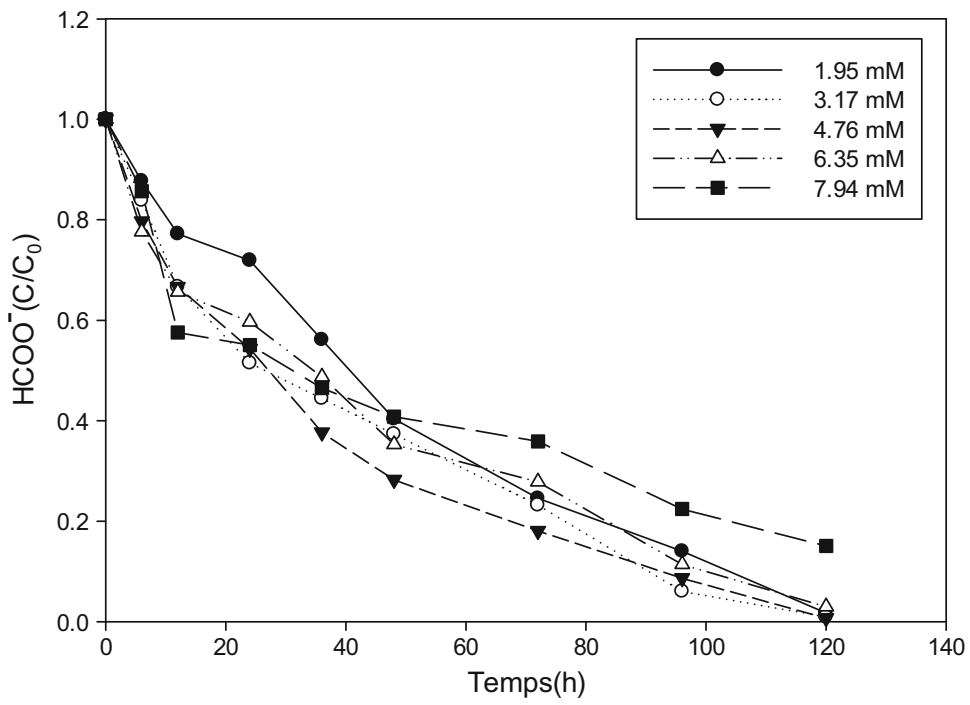


Fig. 5 Variation of formate as a function of time at different concentrations of ammonium formate for the Yarrowia lipolytica strain

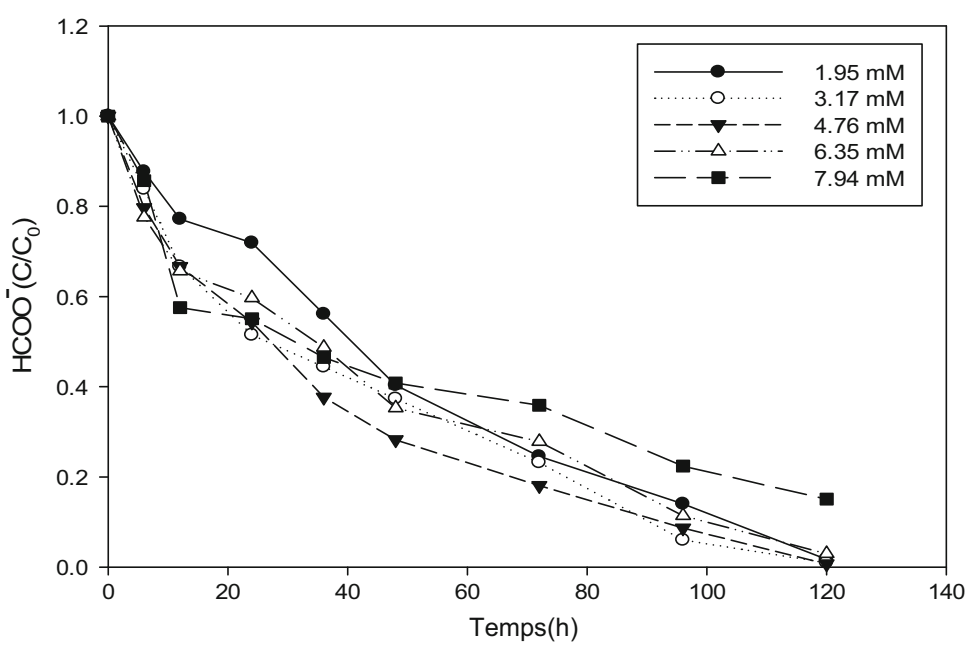

maximum enzymatic activity from $4.76 \mathrm{mM}$ (Dutta et al. 2015; Agarry et al. 2010; Dey and Mukherjee 2010) proposed that this bell-like appearance at high substrate concentrations reveals inhibition by the substrate.

\subsection{Influence of the Formate Concentration} on the Maximum Enzyme Activity

Figure 7 shows the variation of the maximum enzymatic activity as a function of the initial substrate concentration for the two strains studied. We find that the maximum enzyme activity increases with the concentration of formate. This suggests that formate is not responsible for inhibition but rather a primary source of energy. In addition, we find that up to $3 \mathrm{mM}$, both strains have the same maximum enzyme activity. But after this value, the enzymatic activity of Pichia guilliermondii becomes greater than that of Yarrowia lipolytica up to $8 \mathrm{mM}$ where a doubling of this value is observed $\left(0.4 \mu_{\max }\right.$ $\left.\mathrm{h}^{-1}\right)$ for Pichia guilliermondii and $\left(0.2 \mu_{\max } \mathrm{h}^{-1}\right)$ for Yarrowia lipolytica.

\subsection{Estimation of the Model and the Inhibition Parameters by Ammonium Formate}

The biochemical parameters $\left(K_{\mathrm{I}}, K_{\mathrm{M}}, K_{\mathrm{S}}, \mu_{\text {max }}\right)$ as well as the $R^{2}$ and the RSME were estimated using the nonlinear regression of various models presented in
Fig. 6 Influence of the initial ammonium concentration on the maximum enzymatic activity for Yarrowia lipolytica and Pichia guilliermondii strains

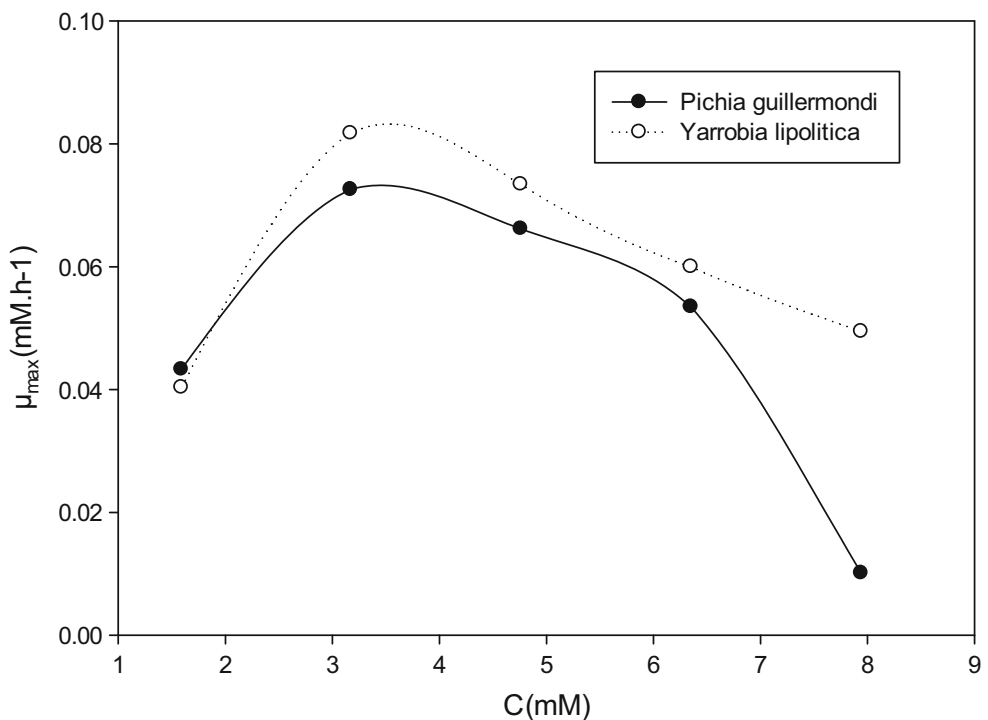


Fig. 7 Influence of the initial formate concentration sur l'activité enzymatique maxiamle for Yarrowia lipolytica and Pichia guilliermondii strains

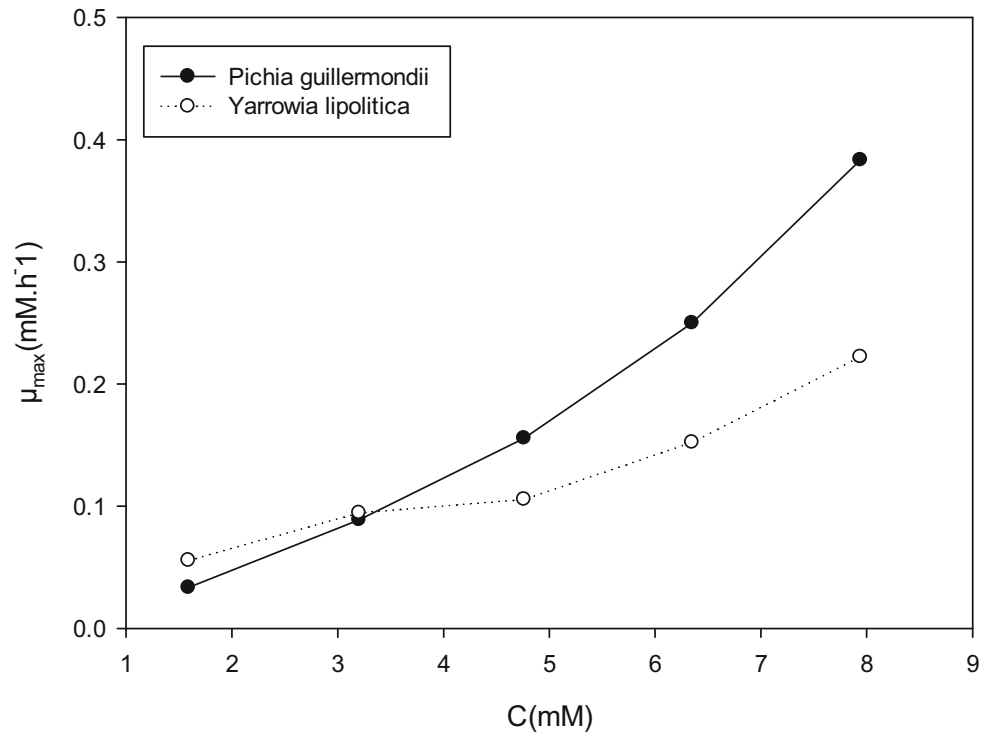

Table 3 for the Pichia guilliermondii strain and Table 4 for the Yarrowia lipolytica strain. It is observed that the Luong model has the highest $R^{2}(0.98)$, followed by the Webb model $\left(R^{2}=0.96\right)$, the Yano model $\left(R^{2}=0.91\right)$, and the Andrews model $R^{2}=0.91$ ), show a good apparent adjustment between the experimental values and the model values for the Pichia guilliermondii strain. Thus, the square root of the mean square of the residuals (RMSE) between the experimental values and the models are respectively $0.0034,0.0053,0.0076$, and 0.0055 for the four models. The Yarrowia lipolytica strain is the Luong model with the highest $R^{2}(0.99)$, followed by the Webb model $\left(R^{2}=0.99\right)$, the Andrews model $\left(R^{2}=0.98\right)$, and finally the Yano model $\left(R^{2}=\right.$ $0.93)$ and the RMSEs are respectively $0.0012,0.00051$,
0.0026 , and $0.0075 . K_{\mathrm{I}}$ values vary from strain to strain and from model to strain. The $K_{\mathrm{i}}$ models of Andrews, Aiba, Webb, Yano, Haldane, and Teisser are respectively $0.47,-6396,-8.54,8.54,0.20$, and $6,45 \mathrm{mM}$ for Pichia guilliermondii and 1.17, - 1.02e 04, 0.09, 0.22, 0.37 , and $7.04 \mathrm{mM}$ for Yarrowia lipolytica. The $K_{\mathrm{I}}$ of the model of Aiba is weak which shows that with this model, the yeasts are insensitive to the inhibition. But for both strains, the $K_{\mathrm{I}}$ values of the Teisser model (4.76 and $5.91 \mathrm{mM})$ and Haldane $(0.65$ and 0.82$)$ are substantially identical for both strains.

The maximum enzymatic activity $\left(\mu_{\max }\right)$ also varies from one strain to another and from one model to another. For Pichia guilliermondii, the highest value of $\mu_{\max }$ is predicted by the Moser model $\left(4.83 \mathrm{~h}^{-1}\right)$ and the

Table 3 Biochemical parameters after the fitting of the different models of inhibition by the substrate following the biodegradation of the ammonium ions for the Pichia guilliermondii strain

\begin{tabular}{|c|c|c|c|c|c|c|c|c|c|c|}
\hline Models & $\mu_{\max }$ & $K_{\mathrm{S}}$ & $K_{\mathrm{I}}$ & $\gamma_{s}^{*}$ & $K$ & $n$ & $m$ & $K_{\mathrm{m}}$ & $R^{2}$ & RMSE \\
\hline Andrews & 0.77 & 34.68 & 1.17 & - & - & - & - & - & 0.98 & 0.0026 \\
\hline Aiba & 0.09 & 2.56 & 13 & - & - & & - & - & 0.89 & 0.0068 \\
\hline Moser & 0.24 & 0.25 & - & - & - & 0.29 & - & - & 0.76 & 0.010 \\
\hline Webb & 0.26 & 0.89 & 0.094 & - & 0.91 & - & - & - & 0.99 & 0.00051 \\
\hline Luong & 2.51 & 172.2 & & 162.7 & & 0.63 & - & - & 0.98 & 0.0012 \\
\hline Edward & 0.02 & 0.95 & 0.22 & & 0.26 & - & - & - & 0.93 & 0.0075 \\
\hline Haldane & 0.09 & 0.65 & 0.37 & 50.71 & - & - & - & - & 0.89 & 0.0096 \\
\hline Teisser & 0.44 & 4.76 & 7.04 & - & - & - & - & - & 0.92 & 0.0059 \\
\hline Han-Levenspiel & 0.18 & - & - & 48.67 & - & 43 & 4 & 503.04 & 0.78 & 0.02 \\
\hline
\end{tabular}


Table 4 Biochemical parameters after the fitting of the different models of inhibition by the substrate following the biodegradation of the ammonium ions for the strain Yarrowia lipolytica

\begin{tabular}{|c|c|c|c|c|c|c|c|c|c|c|}
\hline Models & $\mu_{\max }$ & $K_{\mathrm{S}}$ & $K_{\mathrm{I}}$ & $\gamma_{s}^{*}$ & $K$ & $n$ & $m$ & $K_{\mathrm{m}}$ & $R^{2}$ & RMSE \\
\hline Andrews & 1.31 & 71.14 & 0.47 & - & - & - & - & - & 0.91 & 0.0055 \\
\hline Aiba & 0.07 & 2.24 & 6396 & & & & - & - & 0.72 & 0.0096 \\
\hline Moser & 4.83 & 4.96 & - & - & - & 0.36 & - & - & 0.60 & 0.011 \\
\hline Webb & 0.98 & 4.09 & 8.24 & - & 4.11 & - & - & - & 0.95 & 0.0053 \\
\hline Edward & 1.65 & 33.16 & & 29.4 & & 0.56 & - & - & 0.98 & 0.0034 \\
\hline Yano & 0.0015 & 43.29 & 8.54 & & 6.05 & - & - & - & 0.91 & 0.0076 \\
\hline Haldane & 0.068 & 0.82 & 0.20 & 16.29 & - & - & - & - & 0.72 & 0.013 \\
\hline Teisser & 1.586 & 5.91 & 6.45 & & & & & & 0.87 & 0.0064 \\
\hline Han-Levenspiel & 0.21 & - & - & 77.21 & - & 57 & 3 & 430 & 0.67 & 0.031 \\
\hline
\end{tabular}

lowest by the Yano model $\left(0.0015 \mathrm{~h}^{-1}\right)$. The highest value of $\mu_{\max }$ is predicted by the Luong model $\left(2.51 \mathrm{~h}^{-1}\right)$ and the lowest by the Yano model $\left(0.021 \mathrm{~h}^{-1}\right)$ for the Yarrowia lipolytica strain. Agarwal et al. (2009) modeling the degradation of insoluble cellulose found that the Han-Levenspiel model gives an ideal value. Agarry and Solomon in 2008 studied the degradation of phenol by the fluorescence of Pseudomonas and observed that the experimental data of $\mu_{\max }$ corresponded well to the Haldane model. Dutta et al. in 2015 by studying the production of cutinase by Pseudomonas cepacia did not conclude on the ideal model. Tazda et al. 2013 found that the Yano and Andrews model best showed $\mu_{\max }$ when biodegradation of malathion. The Luong and Haldane models predict the critical substrate concentration at which enzymatic activity is nothing. The critical concentrations for the Luong and Haldane models are 29.4 and $16.29 \mathrm{mM}$ for Yarrowia lipolytica and 162.7 and $50.71 \mathrm{mM}$, respectively. The observation that emerges is that no model is standard to inhibitions by substrates. Different models could be applied to different systems.

\section{Conclusion}

In this study, the biodegradation of ammonium formate by Yarrowia lipolytica and Pichia guilliermondii isolated from a rubber effluent was studied by following the variation of ammonium ions and formate in an aerated batch reactor. The results show that at $3.17 \mathrm{mM}$, ammonium ions are used as a substrate with an increase in maximum enzyme activity. But beyond this concentration, the maximum enzyme activity decreases. This is not the case for formate; the maximum enzymatic activity increases with the concentration of formate. The observation that emerges is that no model is standard to inhibitions by substrates. Different models could be applied to different systems. The models of Luong and Webb seem to be more appropriate for predicting the observed phenomena of inhibition. For Yarrowia lipolytica, $R^{2}=0.958$ and 0.998 with RSME $=0.005342$ and 0.003433 , for Pichia guilliermondii, $R^{2}=0.999$ and 0.992 with $\mathrm{RSME}=$ 0.0005121 and 0.001212 .

Open Access This article is distributed under the terms of the Creative Commons Attribution 4.0 International License (http:// creativecommons.org/licenses/by/4.0/), which permits unrestricted use, distribution, and reproduction in any medium, provided you give appropriate credit to the original author(s) and the source, provide a link to the Creative Commons license, and indicate if changes were made.

\section{References}

Agarry S. E., Solomon, B. O. (2008). Kinetics of batch microbial degradation of phenols by indigenous Pseudomonas fluorescence. International Journal of Environmental Science and Technology, 5 (2), 223-232, Spring 2008 Turkish Journal of Engineering \& Environmental Sciences.

Agarry, S. E., Solomon, B. O., \& Audu, T. O. K. (2010). Substrate utilization and inhibition kinetics: batch degradation of phenol by indigenous monoculture of Pseudomonas aeruginosa. International Journal for Biotechnology and Molecular Biology Research, 1(2), 22-30.

Agarwal, R., Mahanty, B., \& Dasu, V. (2009). Modeling the growth of Cellulomonas cellulans NRRL B-4567 under 
substrate inhibition during cellulose production. Chemical and Biochemical Engineering Quarterly, 23(2009), 213.

Amrouche, T., Sutyak Noll, K., Wang, Y., Huang, Q., \& Chikindas, M. L. (2010). Antibacterial activity of subtilosin alone and combined with curcumin, poly-lysine, and zinc lactate against listeria monocytogenes strains. Probiotics and Antimicrobial Proteins, 2, 250-257.

Arimoro Francis, O. (2009). Impact of rubber effluent discharges on the water quality and macroinvertebrate community assemblages in a forest stream in the Niger Delta. Chemosphere, 77, 440-449.

Atagana, H. I., Ejechib, O., \& Ogodum, I. (1998). Bacterial associated with degradation of wastes from rubber processing industries. Environmental Monitoring and Assessment, 59, $145-154$.

Bougard, D. (2004). Traitement biologique d'effluents azotés avec arrêt de la nitrification au stade nitrite. Thèse de doctorat: Ecole Doctorale : Science et procédé biologiques et industriels.

Cherian, E., \& Jayachandran, K. (2009). Microbial degradation of natural rubber latex by a novel species of Bacillus sp. SBS25 isolated from soil. International Journal of Environmental Research, 3, 599-604.

Dey, S., \& Mukherjee, S. (2010). Performance and kinetic evaluation of phenol biodegradation by mixed microbial culture in a batch reactor. International Journal of Water Resources and Environmental Engineering, 2(3), 40-49.

Dobrovolná, Z., \& Ervený, L. (2000). Ammonium formate decomposition using palladium catalyst. Res. Chem. intermed., 26(5), 489-497.

Dutta, K. V., Dasu, V., Mahanty, B., \& Anand Prabhu, A. (2015). Substrate inhibition growth kinetics for cutinase producing Pseudomonas cepacia using tomato-peel extracted cutin. Chemical and Biochemical Engineering Quarterly, 29(3), 437-445.

EPA USA (Environmental Protection Agency). (2016). Table 4: Protective Action Criteria (PAC) Rev. 29 based on applicable 60-minute AEGLs, ERPGs, or TEELs. The chemicals are listed in alphabetical order and the values are presented in $\mathrm{mg} / \mathrm{m}^{3}$.

Ndi, K. S., Mengue, J.-J. N. N., Kofa, G. P., Bessalla, P. E., Amba, V., \& Kayem, J. G. (2016). Evaluation of the duration of inoculation of a granular pozzolan biofilter from strains of indigenous bacteria and yeasts isolated from a rubber industry effluent. Revue des Sciences de l'Eau, 29(1), 27-34.

Nsoe, J. J. N., Mohammadou, Ndi, K. S., Amba, E. V., Kofa, G. P., Kenfack, A. J., \& Kayem, G. J. (2013). Isolement et caractérisation des levures endogènes à fort potentiel de croissance dans les effluents de caoutchouc, $20^{\mathrm{e}}$ conférence annuelle du comité camerounais de biosciences.

Nsoe, M. N, Nguemtue, T., Kofa, G. P., Amba, E. V., Ngwane, L. N., Kenfack, T. A., Ndi, K. S., Kayem, G. J., Marc, H.
(2016). Impact assessment on the waste from the rubber factories in Cameroon. Asian Academic Research Associates volume 3, Issue 6, June, ISSN: 2319-2801.

Peitz, D. (2012). Investigations on the catalytic decomposition of guanidinium formate, ammonium formate and methanamide as NH3-precursors for the selective catalytic reduction of NOx. Doctor of Sciences. University of ErlangenNuremberg.

Pillai, J. S., \& Girish, K. (2014). Rubber processing industry effluent treatment using a bacterial consortium. International Journal of Current Microbiology and Applied Sciences, 3(10), 775-782.

Rubber, L. M. C. (2013). Rubber and tyre market report. LMC International.

Seneviratne, W. M. G. (1997). Waste water from raw rubber processing industry in Sri Lanka and related environmental aspects. Bulletin Rubber Research Institute of Sri Lanka, 1997(35), 42-48.

Senthil, P., Jeyachandran, S., Manoharan, C., \& Vijayakumar, S. (2012). Microbial diversity in rubber industry effluent. International Journal of Pharma and Bio Sciences, 2012(2), 123-131.

Shruthi, S., Raghavendra, M. P., Swarna Smitha, H. S., \& Girish, K. (2012). Bioremediation of rubber processing industry effluent by Pseudomonas sp. International Journal of Environmental and Science and Technology, 2, 27-30.

Sridhar, M., van Bokhoven, J. A., \& Kröcher, O. (2014). Effect of ammonia on the decomposition of ammonium formate over $\mathrm{Au} / \mathrm{TiO} 2$ under oxidizing conditions relevant to SCR: enhancement of formic acid decomposition rate and ? $\mathrm{CO}_{2}$ ? production. Applied Catalysis A : General, 486(2014), 219-229.

Sulaiman, N. M. N., Ibrahim, S., \& Abdullah, S. L. (2010). Membrane bioreactor for the treatment of natural rubber wastewater. International Journal of Environmental Engineering, 2(1/2/3), 92-109.

Swarna Smitha, H. S., Raghavendra, M. P., Shruthi, S., \& Girish, K. (2012). Bioremediation of rubber processing industry effluent by Arthrobacter sp. International Journal of Research in Environmental Science and Technology.

Tazda, D., Abdi, N., Grib, H., Lounici, H., Pauss, A., \& Mameri, N. (2013). Comparison of different models of substrate inhibition in aerobic batch biodegradation of malathion. Turkish Journal of Engineering and Environmental Sciences, 37, 221-230.

Tekasakul. (2010). Environmental problems related to natural rubber production in Thailand. Journal of Aerosol Research, 21, 122-129.

Vadivelu, V. M., Keller, J., \& Yuan, Z. (2007). Effect of free ammonia on the respiration and growth processes of an enriched Nitrobacter culture. Water Research, 41(4), 826834. 